\title{
Assessment of DNA Damage in the Peripheral Lymphocytes of Patients with Parkinson's Disease and Multiple Sclerosis Using the Comet Assay
}

\author{
Parkinson ve Multipl Skleroz Hastalarının \\ Periferal Lenfositlerindeki DNA Hasarının \\ Comet Yöntemiyle Değerlendirilmesi
}

\author{
Mustafa BAYDAR, ${ }^{\text {a }}$ \\ Sevtap AYDIN, ${ }^{b}$ \\ Ülkü BUCURGAT ÜNDEĞER, ${ }^{b}$ \\ Gürdal ORHAN, ${ }^{\circ}$ \\ Fikri AK, ${ }^{c}$ \\ Nurşen BAŞARAN ${ }^{b}$
}

Clinics of

${ }^{\mathrm{a} A n e s t h e s i o l o g y}$ and Reanimation,

${ }^{c} 2^{\text {nd }}$ Neurology Clinic,

Numune Training and Research Hospital, bepartment of

Pharmaceutical Toxicology,

Hacettepe University

Faculty of Pharmacy, Ankara

Geliş Tarihi/Received: 07.06.2012

Kabul Tarihi/Accepted: 07.03.2013

Yazışma Adresi/Correspondence:

Ülkü BUCURGAT ÜNDEĞER

Hacettepe University

Faculty of Pharmacy,

Department of

Pharmaceutical Toxicology, Ankara, TÜRKIYE/TURKEY

uundeger@hacettepe.edu.tr

\begin{abstract}
Objective: It has been suggested that oxidative damage have been involved in the pathogenesis of neurodegenerative diseases. Although the role of oxidative stress in the etiology of these diseases is not clear, the increased levels of DNA damage and protein as well as DNA and mitochondrial oxidation have been demonstrated in patients with Parkinson's disease (PD) and Alzheimer's disease (AD) in a few studies. Material and Methods: In this study, the levels of DNA damage in the peripheral lymphocytes of patients with PD and multiple sclerosis (MS), and their age-matched healthy controls were determined by the comet assay with and without treatment of blood samples with $50 \mu \mathrm{M}$ hydrogen peroxide (H2O2) and the oxidative purine specific DNA repair enzyme, formamidopyrimidine glycosylase (Fpg). Results: The DNA damage in the lymphocytes of the patients with PD has been significantly increased compared to controls. However, no significant increase in the DNA strand breakage was detected in the patients with PD after treatment with either H2O2 or Fpg. Although the DNA damage in the MS patients was higher than their healthy controls, the difference was not found to be significant. A significant increase observed in the DNA damage after treatment with $\mathrm{H} 2 \mathrm{O} 2$ and with Fpg in MS patients, have suggested the susceptibility to oxidative DNA damage in these patients. Conclusion: The data presented in this paper shows high level of DNA damage in the lymphocytes of patients with PD and MS which indicates the possibility of oxidative stres in these neurodegenerative diseases.
\end{abstract}

Key Words: Neurodegenerative diseases; multiple sclerosis; Parkinson disease; DNA damage; comet assay

ÖZET Amaç: Sinir dokusunun bozulumu ile ilgili hastalıkların gelişiminde oksidatif hasarın katkısı olduğu öne sürülmektedir. Bu hastalıkların etiyolojisinde oksidatif baskının rolü açık olmamakla birlikte, Parkinson hastalarında $(\mathrm{PH})$ ve Alzheimer hastalarında $(\mathrm{AH})$ DNA hasarının ve protein, DNA ve mitokondri oksidasyonunun arttı̆̆ını gösteren az sayıda çalışma bulunmaktadır. Gereç ve Yöntemler: Bu çalışmada, Parkinson ve Multipl Skleroz (MS) hastalarının ve yaşları eşleştirilmiş sağlıklı kontrollerinin periferal lenfositlerindeki DNA hasar düzeyi, kan örneklerine $50 \mu \mathrm{M}$ hidrojen peroksit $\left(\mathrm{H}_{2} \mathrm{O}_{2}\right)$ ve oksidatif pürin özgül DNA onarım enzimi, formamidopirimidin glikozilaz (Fpg) uygulamasından önce ve sonrasında Comet yöntemiyle saptanmıştır. Bulgular: Parkinson hastalarının lenfositlerinde DNA hasarı kontrollere kıyasla önemli şekilde artmıştır. Bununla birlikte, Parkinson hastalarının lenfositlerindeki DNA iplik kırıklarında $\mathrm{H}_{2} \mathrm{O}_{2}$ ya da Fpg uygulaması ile önemli artış meydana gelmemiştir. MS hastalarının DNA hasarı sağlıklı kontrollerininkine kıyasla yüksekken, aradaki fark istatistiksel olarak anlamlı bulunmamıştır. MS hastalarının lenfositlerindeki DNA hasarında $\mathrm{H}_{2} \mathrm{O}_{2}$ ve Fpg uygulamasının ardından önemli artış gözlenmiştir, bu hastaların oksidatif DNA hasarına duyarlı oldukları ileri sürülmüştür. Sonuç: Bu makalede sunulan sonuçlar, Parkinson ve MS hastalarının lenfositlerindeki yüksek düzey DNA hasarını ve aynı zamanda sinir dokusunun bozulumu ile ilgili hastalıklarda oksidatif baskı olasılığını göstermektedir.

Anahtar Kelimeler: Nörodejeneratif hastalıklar; multipl skleroz; Parkinson hastalığı; DNA hasarı; comet assay

doi: 10.5336/medsci.2012-30877

Copyright ( 2013 by Türkiye Klinikleri
Turkiye Klinikleri J Med Sci 2013;33(4):936-45 
$\mathrm{N}$ eurodegenerative diseases are a group of nervous system disorders that are characterized by progressive death of various neurons to impair the motor functions, memory, emotional conditions, and learning. The group includes Alzheimer's disease (AD), amyotrophic lateral sclerosis, spinal muscular atrophy, myotonic dystrophy, Parkinson's disease (PD), and Multiple Sclerosis (MS), etc. The etiology of most neurodegenerative disorders is multifactorial and consists of an interaction between environmental factors and genetic predisposition. ${ }^{1-4}$ Oxidative stress resulting from an imbalance between the formation of free radicals and the antioxidant defense systems, may be a potential pathophysiological factor involved in the degenerative processes. Although the role played by oxidative stress in neurodegenerative diseases remains undefined, some previous studies mostly on $\mathrm{AD}$ have provided evidence of the involvement of oxidative damage in the pathogenesis of neurodegenerative diseases. ${ }^{5-10}$ Since brain has many metabolic activities, high energy requirements and a high oxygen consumption rate, it can be exposed to reactive oxygen species deeply. It is estimated that oxidative stress can be an important factor in degenerative neural death and disease progression. Increased levels of redox active iron and lipid peroxidation, increased RNA oxidation and nuclear DNA oxidation, increased mitochondrial oxidation, decreased level of neural polyunsaturated fatty acid and protein oxidation have been demonstrated in patients with $\mathrm{AD} \cdot{ }^{11-16}$

A significantly higher levels of basal and oxidative DNA damage were found in the lymphocytes as well as in the polymorphonuclear leukocytes of patients with $\mathrm{AD}$ and with mild cognitive impairment (MCI). ${ }^{17-19}$ Studies in patients with $\mathrm{AD}$ showed increased levels of 8-hydroxyguanosine (8OHG) or 8-hydroxy-2'-deoxyguanosine $(8 \mathrm{OHdG})$ in addition to decreased levels of plasma antioxidants as compared to controls. ${ }^{5,11,17,20-}$ ${ }^{23}$ On the other hand, most studies on patients with $\mathrm{AD}$ have been performed in post-mortem tissues with advanced disease without clarifying whether oxidative stress is an early event or a common final step secondary to the degenerative process. Only relatively small number of studies have been performed in living patients with $\mathrm{AD}$ suggesting that oxidative stress in $\mathrm{AD}$ is detectable not only in the central nervous system, but also in peripheral cells. ${ }^{11,17-19,24}$

PD which is characterized by a severe neurodegeneration of the mesencephalic dopaminergic neurons in the substantia nigra, is one of the most common neurodegenerative diseases affecting about $2 \%$ of the population over 60 years. ${ }^{25}$ It causes extrapyramidal motor dysfunction as tremor, rigidity, and dyskinesia. The pathogenic mechanism of the disease is not clear and oxidative stress seems to be one of the main etiological factors. Protein oxidation has been demonstrated to be elevated in Lewy bodies in cases of PD. There are also a few studies indicating the elevated levels of oxidative DNA damage in the lymphocytes of patients with PD. ${ }^{26-29}$

MS is a common, often disabling disease of the central nervous system. Although it is generally accepted that vascular factors, metabolic alterations, viral infections of the central nervous system and disturbed immune mechanisms are responsible, little is known about its cause or the factors that contribute to its unpredictable course. ${ }^{30,31}$

In the present study, in order to investigate the possible role of oxidative stress in neurodegerative diseases, the levels of DNA damage, susceptibility to oxidative DNA damage in peripheral lymphocytes of patients with MS and PD and their comparable age-matched healthy controls were determined by single cell gel electrophoresis or comet technique which has been in use for many years as a sensitive method to detect DNA single strand breaks, and alkaline-labile sites, DNA-DNA or DNA-protein crosslinking and also oxidative DNA adducts and SSBs associated with incomplete excision repair sites in single cells. ${ }^{32}$

\section{MATERIAL AND METHODS}

\section{SUBJECTS}

The study consisted of 25 patients with PD (7 females and 18 males, mean age of $64 \pm 2.8$ years and age range of 31-86 years) and 22 MS patients (16 
females and 6 males, with a mean age of $36 \pm 2.6$ years and age range of 22-66 years) who were the outpatients of the Numune Education and Research Hospital, $2^{\text {nd }}$ Neurology Clinic, Ankara Turkey. For PD patients, 14 healthy subjects (12 females and 2 males, with a mean age of $59 \pm 4.5$ years, age range of 30-81 years), and for MS patients, 16 healthy subjects ( 13 females and 3 males, with the mean age of $40 \pm 3.6$ years and age range of 19-68 years) of comparable age, socioeconomic life-style and smoking habits were chosen as controls. The study has been approved by the local ethics committee according to the 'Decleration of Helsinki'. The clinical diagnosis of PD was based on the presence of the symptoms of postural instability according to UK Parkinson's Disease Society Bank Criteria whereas MS patients were diagnosed according to McDonald's Criteria. Eighteen PD patients had been treated with levodopa plus dopa-dicarboxylase (DDC) inhibitors such as benserazide and carbidopa for more than 5 years and the remaining 7 patients had been treated with other drugs such as galantamine, pramipexole. Fourteen MS patients were not using drug therapy at the time of the study whereas $8 \mathrm{MS}$ patients had been treated with interferon. Standardized health questionnaires from all patients and controls relating to their occupational exposure and life-style factors such as smoking, drug consumption, viral diseases, radiodiagnostic examinations and dietary habits were obtained. None of the control subjects had verifiable symptoms of dementia or other internal and neurological disorders, as judged by their clinical examination in which results of routine physical, neurological and neuropsychological tests were within the normal values. None of the subjects had also been taking antioxidants such as vitamin E or any kind of medication known to interfere with the redox state of the body or to cause oxidative or DNA damage. All participating subjects were provided with a written informed consent before their blood samples were drawn.

\section{BLOOD SAMPLES AND CELL PREPARATION}

$2 \mathrm{ml}$ heparinized whole blood was collected by venipuncture from the patients and the controls. Lymphocytes were isolated immediately by Ficoll-
Hypaque density gradient and washed with PBS. ${ }^{33}$ An aliquot of cells was used to check for viability by trypan blue exclusion.

\section{SLIDE PREPARATION}

The basic alkaline technique of Singh et al., described by Collins et al. was followed. ${ }^{34,35}$ All microscopic slides had been covered with 1\% NMA at about $45{ }^{\circ} \mathrm{C}$ in $\mathrm{Ca}^{2+}$ - and $\mathrm{Mg}^{2+}$ - free PBS before the experiment. This layer was used to promote the attachment of the second layer. For the second layer, around 10000 cells mixed with $80 \mu \mathrm{l}$ of $1 \%$ LMA ( $\mathrm{pH}$ 7.4) were rapidly pipetted onto this slide, spread using a cover slip, and maintained on an icecold flat tray for 5 min to solidify. After removal of the cover slip, the slides were immersed in cold, freshly prepared lysing solution $(2.5 \mathrm{M} \mathrm{NaCl}, 100$ $\mathrm{mM} \mathrm{Na}{ }_{2}$ EDTA, $10 \mathrm{mM}$ Tris, $1 \%$ sodium sarcosinate, $\mathrm{pH} 10$ ) with $1 \%$ Triton $\mathrm{X}-100$ and $10 \%$ DMSO added just before use, for a minimum of $1 \mathrm{~h}$ at $4 \stackrel{\circ}{\circ}$ to remove cellular proteins. Each analysis was done in duplicate and carried out immediately after sample collection without freezing or storing. For Fpg-modified comet assay; after lysis and slides having $\mathrm{H}_{2} \mathrm{O}_{2}$ treated cells were washed three times for $5 \mathrm{~min}$ in enzyme buffer (20mM Tris $\mathrm{HCl}, 1 \mathrm{mM}$ $\mathrm{Na}_{2}$ EDTA, $100 \mathrm{mM} \mathrm{NaCl}, 0.5 \mathrm{mg} \mathrm{BSA} / \mathrm{ml}, \mathrm{pH}$ 7.0). Then, $6 \mu$ agarose MEEO was placed at the corners of a coverslip and slides were incubated with $200 \mu \mathrm{l}$ of Fpg in enzyme buffer solution. Control slides were treated with $200 \mu$ l enzyme buffer only. Slides were placed horizontally in humidity chamber at $37{ }^{\circ} \mathrm{C}$ for $30 \mathrm{~min}$. DNA unwinding and electrophoresis were then completed as described below.

\section{ELECTROPHORESIS}

The slides were removed from the lysing solution, drained and placed in horizontal gel electrophoresis tank side by side, avoiding spaces and with the agarose ends facing each other, nearest the anode. The tank was filled with fresh electrophoresis solution (1 mM Na 2 EDTA and $300 \mathrm{mM} \mathrm{NaOH}, \mathrm{pH}$ 13) to a level approximately $0.25 \mathrm{~cm}$ above the slides. Before electrophoresis, the slides were left in the solution for $20 \mathrm{~min}$ at $4^{\circ} \mathrm{C}$ to allow the unwinding of the DNA and expression of alkaline la- 
bile damage. Electrophoresis was conducted at a low temperature $(4 \stackrel{\circ}{\circ})$ for 20 min using $24 \mathrm{~V}$ and adjusting the current to $300 \mathrm{~mA}$ by raising or lowering the buffer level and using a compact power supply (Power Pack P 25 Biometra Analytic $\mathrm{GmbH})$. All of these steps were conducted under dimmed light to prevent the occurrence of an additional damage. After electrophoresis, the slides were taken out of the tank, washed in distilled water. Tris buffer (0.4 M Tris, $\mathrm{pH}$ 7.5) was added drop-wise and gently to neutralize the excess alkali and the slides were allowed to sit for $5 \mathrm{~min}$. The neutralizing procedure was repeated 3 times. After waiting the slides each for $5 \mathrm{~min}$ in distilled water, $50 \%, 75 \%$ and $99 \%$ ethanol they were allowed to dry at room temperature.

\section{STAINING AND SLIDE SCORING}

To each slide, $30 \mu \mathrm{l}$ of $\mathrm{EtBr}(20 \mu \mathrm{l} / \mathrm{ml})$ was added. For visualization of DNA damage, slides were examined at a $1000 \mathrm{X}$ magnification using a $40 \mathrm{X}$ objective on a fluorescence microscope Leica (Wetzlar, Germany). Measurements were made by a computer-based image analysis system 'Comet Assay III' Perceptive Instruments (Suffolk, England). Images of 100 randomly selected lymphocytes, i.e. 50 cells from each of two replicate slides were analyzed from each sample and tail migration, tail moment and tail intensity were measured. Breaks in the DNA molecule disturb its complex supercoiling, allowing liberated DNA to migrate towards the anode. Staining shows the DNA as 'comets'. The mean value of the tail migration, tail moment and tail intensity was calculated and used for the evaluation of DNA damage.

\section{STATISTICAL ANALYSIS}

The SPSS 11.5 for Windows computer program was used for statistical analysis. Statistical comparison of the results from controls and patients with PD and MS, were carried out by Mann-Whitney U test. Intragroup comparisons for the differences between peripheral lymphocytes, $\mathrm{H}_{2} \mathrm{O}_{2}$-treated peripheral lymphocytes, and $\mathrm{FPG}+\mathrm{H}_{2} \mathrm{O}_{2}$-treated peripheral lymphocytes were evaluated by Wilcoxon Sign Rank tests. The percent change values of $\mathrm{H}_{2} \mathrm{O}_{2}$-treated peripheral lymphocytes and
Fpg $+\mathrm{H}_{2} \mathrm{O}_{2}$-treated peripheral lymphocytes were calculated according to peripheral lymphocytes and $\mathrm{H}_{2} \mathrm{O}_{2}$-treated peripheral lymphocytes, respectively. Results were expressed as median (minimum-maximum). $\quad \mathrm{p}<0.05$ was considered statistically significant.

\section{RESULTS}

Cell viability, as tested using trypan blue dye exclusion of each treated group, was more than $90 \%$. The DNA damage expressed as tail migration, tail moment and tail intensity in the lymphocytes of the patients with PD and MS and also their healthy controls are given in tables (Table 1-3). The DNA damage was found to be significantly higher in patients with PD compared to their healthy controls $(\mathrm{p}<0.05)$. However, no significant increase in DNA strand breakage was found after treatment with only $\mathrm{H}_{2} \mathrm{O}_{2}$ and with $\mathrm{H}_{2} \mathrm{O}_{2}$ and Fpg in the lymphocytes of patients with $\mathrm{PD}$ compared to their healthy controls (Figure 1).

Although the basal DNA damage was higher in MS patients compared to their healthy controls, the difference was not statistically significant. Although no significant difference was found in the tail migration and tail intensity of the patients and controls, a significant increase in the tail moment after treatment of lymphocytes with $\mathrm{H}_{2} \mathrm{O}_{2}$ and post-treatment with Fpg have been observed in the patients with MS compared to their healthy controls (Figure 2).

\section{DISCUSSION}

The brain is only $2-3 \%$ of the total body mass, but it consumes $20 \%$ of the body oxygen. Cells in the brain are particularly susceptible to oxidative damage due to the high levels of polyunsaturated fatty acids in their membranes and relatively low activity of endogenous antioxidant enzymes. On the other hand, aging is also associated with increased oxidative stress and accumulation of oxidatively damaged biomolecules which gradually weakens cognition. The increase in oxidative stress together with the decline in endogenous antioxidants are important underlying risk factors for older people to develop neurodegenerative diseases. ${ }^{36-38}$ More 
TABLE 1: Assessment of DNA damage as expressed tail migration in peripheral blood lymphocytes of patients with Parkinson's disease (PD) and multiple sclerosis (MS) and their healthy controls. ${ }^{a}$

\begin{tabular}{|c|c|c|c|c|c|c|}
\hline & $\begin{array}{c}\text { (A) PD patients } \\
(n=25)\end{array}$ & $\begin{array}{l}\text { (B) Controls of } \\
\text { PD patients } \\
(n=14)\end{array}$ & $\mathrm{p}$ & $\begin{array}{c}\text { (C) MS patients } \\
(\mathrm{n}=22)\end{array}$ & $\begin{array}{l}\text { (D) Controls of } \\
\text { MS patients } \\
(n=16)\end{array}$ & $\mathrm{p}$ \\
\hline (E) Peripheral lymphocytes & $19.61(13.23 ; 41.03)$ & $16.76(14.78 ; 20.67)$ & 0.016 & $17.35(14.13 ; 31.64)$ & $17.67(13.90 ; 21.77)$ & 0.827 \\
\hline (F) $\mathrm{H}_{2} \mathrm{O}_{2}$ Treated peripheral & $27.53(17.53 ; 49.90)$ & $30.23(16.91 ; 46.8)$ & 0.761 & $28.27(9.73 ; 43.44)$ & $22.27(16.91 ; 39.18)$ & 0.084 \\
\hline Lymphocytes & $0.36(-0.33 ; 2.77)^{b}$ & $0.59(-0.05 ; 2.04)^{b}$ & & $0.53(-0.31 ; 1.80)^{b}$ & $0.22(-0.05 ; 1.54)^{b}$ & \\
\hline (G) $\mathrm{Fpg}+\mathrm{H}_{2} \mathrm{O}_{2}$ treated & $39.18(24.63 ; 59.32)$ & $39.97(30.89 ; 50.53)$ & 0.965 & $44.93(11.33 ; 78.99)$ & $38.80(30.89 ; 49.22)$ & 0.162 \\
\hline Peripheral lymphocytes & $0.38(-0.38 ; 2.06)^{c}$ & $0.33(-0.21 ; 1.84)^{c}$ & & $0.54(-0.10 ; 2.42)^{c}$ & $0.63(-0.21 ; 1.84)^{c}$ & \\
\hline \multicolumn{7}{|l|}{ Within comparison } \\
\hline$(E)-(F)$ & 0.001 & 0.002 & & $<0.001$ & 0.001 & \\
\hline$(F)-(G)$ & $<0.001$ & 0.004 & & $<0.001$ & 0.001 & \\
\hline
\end{tabular}

aThe results are given as median (minimum-maximum).

bSecond row gives the summarize of percent change values according to peripheral lymphocytes.

'Second row gives the summarize of percent change values according to $\mathrm{H}_{2} \mathrm{O}_{2}$ treated peripheral lymphocytes.

TABLE 2: Assessment of DNA damage as expressed tail moment in peripheral blood lymphocytes of patients with Parkinson's disease (PD) and multiple sclerosis (MS) and their healthy controls. ${ }^{a}$

\begin{tabular}{|c|c|c|c|c|c|c|}
\hline & $\begin{array}{c}\text { (A) PD patients } \\
(n=25)\end{array}$ & $\begin{array}{l}\text { (B) Controls of } \\
\text { PD patients } \\
(n=14)\end{array}$ & $\mathrm{p}$ & $\begin{array}{l}\text { (C) MS patients } \\
(n=22)\end{array}$ & $\begin{array}{l}\text { (D) Controls of } \\
\text { MS patients } \\
(n=16)\end{array}$ & $p$ \\
\hline (E) Peripheral lymphocytes & $0.89(0.29 ; 8.82)$ & $0.67(0.22 ; 1.13)$ & 0.008 & $0.62(0.17 ; 3.79)$ & $0.61(0.29 ; 3.62)$ & 0.988 \\
\hline (F) $\mathrm{H}_{2} \mathrm{O}_{2}$ Treated peripheral & $3.65(0.30 ; 11.56)$ & $5.05(0.56 ; 13.15)$ & 0.740 & $4.20(0.55 ; 18.07)$ & $1.98(0.56 ; 6.33)$ & 0.024 \\
\hline Lymphocytes & $0.60(-0.68 ; 38.86)^{b}$ & $6.48(-0.40 ; 25.59)^{b}$ & & $3.71(-0.05 ; 38.76)^{b}$ & $1.44(-0.40 ; 9.38)^{b}$ & \\
\hline (G) $\mathrm{Fpg}+\mathrm{H}_{2} \mathrm{O}_{2}$ treated & $6.46(1.30 ; 15.87)$ & $6.05(3.14 ; 12.83)$ & 0.942 & $8.09(1.91 ; 14.74)$ & $5.19(3.14 ; 10.52)$ & 0.009 \\
\hline peripheral lymphocytes & $0.91(-0.34 ; 11.84)^{c}$ & $0.41(-0.47 ; 17.79)^{\mathrm{C}}$ & & $0.90(-0.51 ; 6.48)^{c}$ & $0.90(-0.47 ; 17.79)^{\mathrm{c}}$ & \\
\hline \multicolumn{7}{|l|}{ Within comparison } \\
\hline$(E)-(F)$ & 0.003 & 0.002 & & $<0.001$ & 0.001 & \\
\hline$(\mathrm{F})-(\mathrm{G})$ & $<0.001$ & 0.019 & & 0.006 & 0.002 & \\
\hline
\end{tabular}

aThe results are given as median (minimum-maximum).

bSecond row gives the summarize of percent change values according to peripheral lymphocytes.

'Second row gives the summarize of percent change values according to $\mathrm{H}_{2} \mathrm{O}_{2}$ treated peripheral lymphocytes.

TABLE 3: Assessment of DNA damage as expressed tail intensity in peripheral blood lymphocytes of patients with Parkinson's disease (PD) and multiple sclerosis (MS) and their healthy controls. ${ }^{a}$

\begin{tabular}{|c|c|c|c|c|c|c|}
\hline & $\begin{array}{c}\text { (A) PD patients } \\
(n=25)\end{array}$ & $\begin{array}{l}\text { (B) Controls of } \\
\text { PD patients } \\
(n=14)\end{array}$ & $p$ & $\begin{array}{c}\text { (C) MS patients } \\
(n=22)\end{array}$ & $\begin{array}{l}\text { (D) Controls of } \\
\text { MS patients } \\
(n=16)\end{array}$ & $p$ \\
\hline (E) Peripheral lymphocytes & $6.24(2.64 ; 32.56)$ & $4.47(1.59 ; 7.29)$ & 0.012 & $5.01(1.60 ; 18.79)$ & $4.50(2.08 ; 14.47)$ & 0.510 \\
\hline (F) $\mathrm{H}_{2} \mathrm{O}_{2}$ Treated peripheral & $16.37(2.11 ; 39.28)$ & $21.03(5.00 ; 41.48)$ & 0.654 & $18.96(0.03 ; 39.83)$ & $11.26(5.00 ; 24.92)$ & 0.078 \\
\hline Lymphocytes & $0.22(-0.64 ; 11.22)^{b}$ & $3.41(-0.12 ; 13.92)^{b}$ & & $1.86(-1.00 ; 15.84)^{b}$ & $1.30(-0.12 ; 4.36)^{b}$ & \\
\hline (G) $\mathrm{Fpg}+\mathrm{H}_{2} \mathrm{O}_{2}$ Treated & $26.16(8.77 ; 45.48)$ & $23.69(13.03 ; 44.30)$ & 0.874 & $28.77(0.25 ; 48.79)$ & $21.71(13.03 ; 40.53)$ & 0.201 \\
\hline Peripheral lymphocytes & $0.69(-0.12 ; 6.38)^{c}$ & $0.40(-0.43 ; 7.11)^{c}$ & & $0.72(-0.99 ; 3.04)^{c}$ & $0.62(-0.43 ; 7.11)^{c}$ & \\
\hline \multicolumn{7}{|l|}{ Within comparison } \\
\hline$(E)-(F)$ & 0.005 & 0.001 & & $<0.001$ & 0.001 & \\
\hline$(\mathrm{F})-(\mathrm{G})$ & $<0.001$ & 0.019 & & 0.007 & 0.003 & \\
\hline
\end{tabular}

aThe results are given as median (minimum-maximum).

bSecond row gives the summarize of percent change values according to peripheral lymphocytes.

'Second row gives the summarize of percent change values according to $\mathrm{H}_{2} \mathrm{O}_{2}$ treated peripheral lymphocytes. 

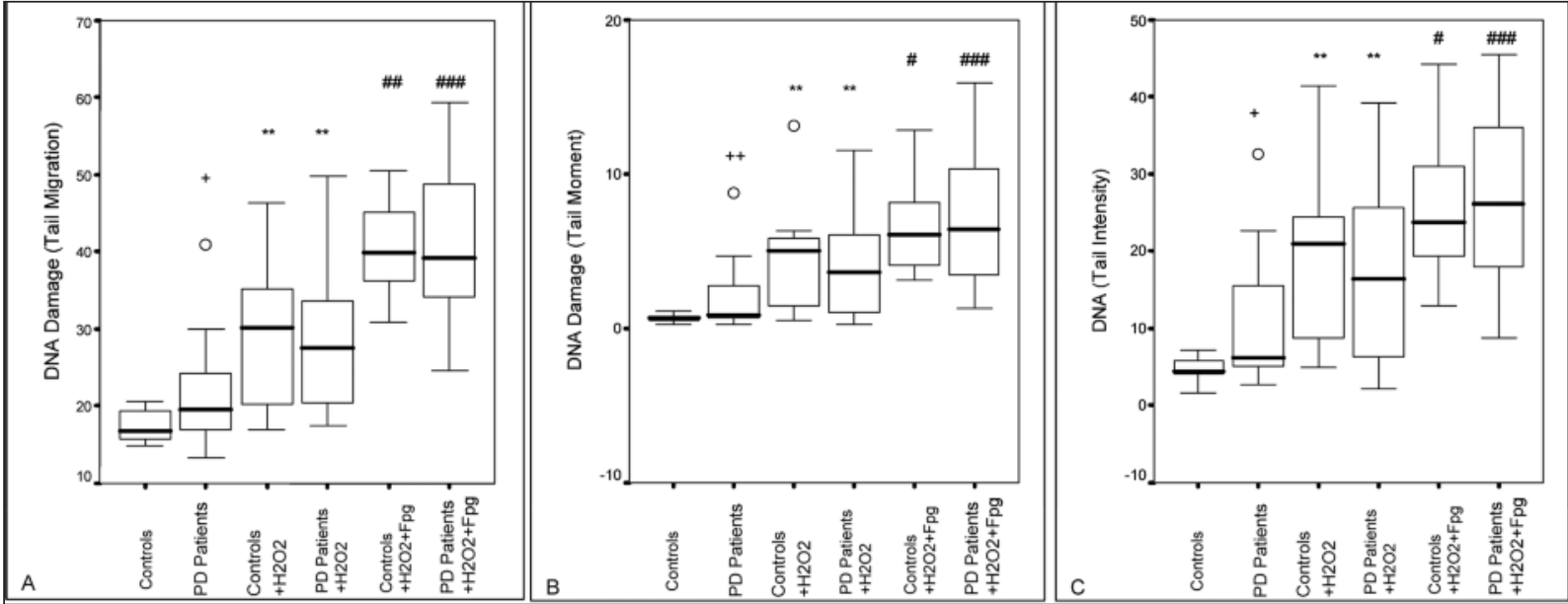

FIGURE 1: Assessment of DNA damage in peripheral blood lymphocytes of patients with Parkinson's disease (PD) and healthy controls. DNA damage in peripheral lymphocytes of the groups expressed as (A) tail migration, (B) tail moment, and (C) tail intensity.

${ }^{* *} \mathrm{p}<0.01$, DNA damage in peripheral lymphocytes of patients with Parkinson's disease and healthy controls compared to their $\mathrm{H}_{2} \mathrm{O}_{2}$ treated samples. ${ }^{\#} \mathrm{p}<0.05$; ${ }^{*} \mathrm{p}<0.01$, \#\# $\mathrm{p}<0.001$, DNA damage in $\mathrm{H}_{2} \mathrm{O}_{2}$ treated peripheral lymphocytes of patients with Parkinson's disease and healthy controls compared to their $\mathrm{H}_{2} \mathrm{O}_{2}+\mathrm{Fpg}$ treated samples.

${ }^{+} p<0.05 ;{ }^{+} p<0.01$, DNA damage in peripheral lymphocytes of patients with Parkinson's disease compared to healthy controls.

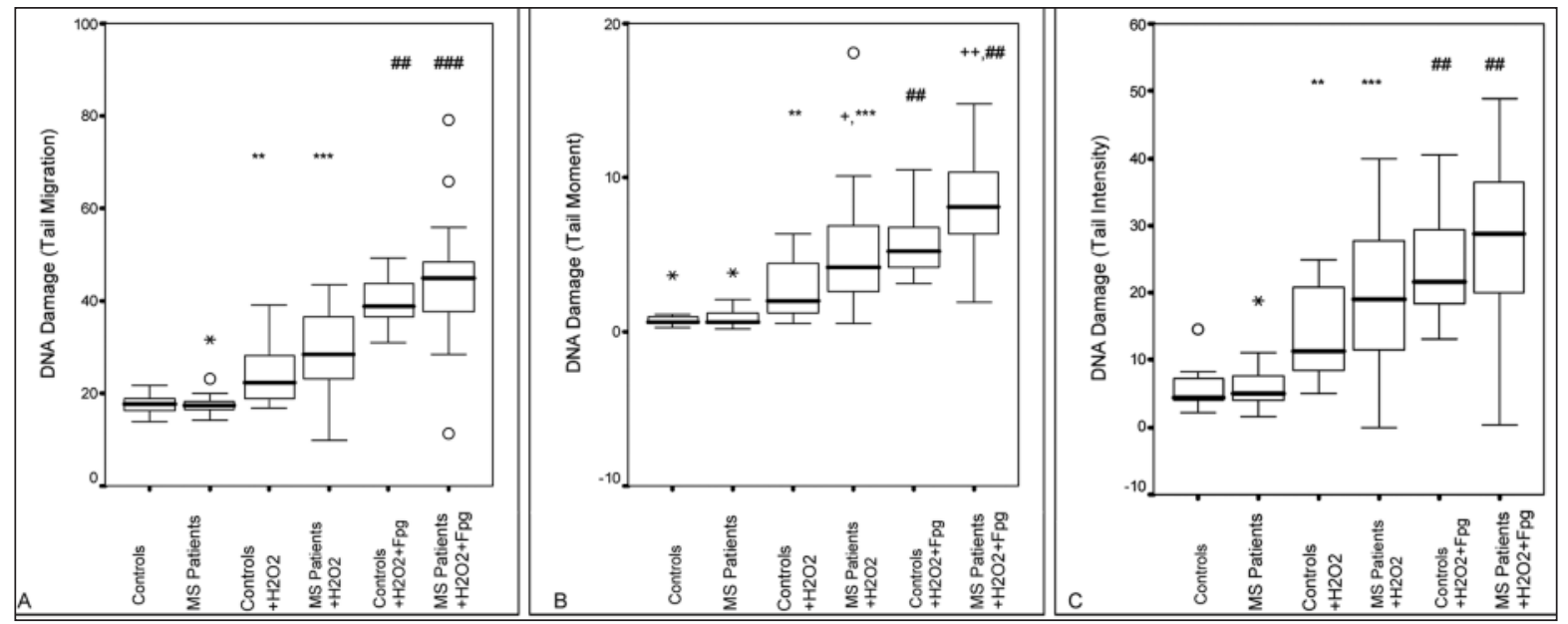

FIGURE 2: Assessment of DNA damage in peripheral blood lymphocytes of patients with multiple sclerosis disease (MS) and healthy controls. DNA damage in peripheral lymphocytes of the groups expressed as (A) tail migration, (B) tail moment, and (C) tail intensity.

${ }^{* *} p<0.01 ;{ }^{* * *} p<0.001$, DNA damage in peripheral lymphocytes of patients with MS and healthy controls compared to their $\mathrm{H}_{2} \mathrm{O}_{2}$ treated samples.

\# $p<0.01$, ${ }^{\# \#} p<0.001$, DNA damage in $\mathrm{H}_{2} \mathrm{O}_{2}$ treated peripheral lymphocytes of patients with $\mathrm{MS}$ and healthy controls compared to their $\mathrm{H}_{2} \mathrm{O}_{2}+\mathrm{Fpg}$ treated samples.

$+p<0.05 ;{ }^{++} p<0.01$, DNA damage in peripheral lymphocytes of patients with MS compared to healthy controls.

oxidized proteins such as carboxyls and nitro-protein adducts were detected in both nuclear and mitochondrial DNA in the elderly brain. Post mortem studies demonstrated increased oxidation of proteins, lipids and DNA in neurodegenerative diseases including $\mathrm{AH}, \mathrm{PD}$, stroke, amyotrophic lateral sclerosis, etc. ${ }^{36-39}$

Studies related to the role of oxidative stress in neurodegenerative diseases are limited with pa- tients with $\mathrm{AD}$ and several studies demonstrated elevated levels of oxidative DNA damage and an impairment in the removal of oxidized purines in the lymphocytes of patients with AD. ${ }^{16-19} \mathrm{~A}$ significant increase of $8 \mathrm{OHG}$ and an oxidized amino acid (nitrotyrosine) were detected in neurons of patients with AD suggesting that increased oxidative damage is an early event in $\mathrm{AD}$ that decreases with the progression of the disease. ${ }^{40}$ The level of oxidative 
damage and repair capacity in peripheral lymphocytes of AD patients and their age-matched controls was determined by the comet assay applied to freshly isolated blood samples with oxidative lesion-specific DNA repair endonucleases. Statistically significant elevation $(\mathrm{p}<0.05)$ of oxidized purines was observed in nuclear DNA of peripheral lymphocytes from $27 \mathrm{AD}$ patients, compared to 12 age-matched control subjects, both at basal level and after oxidative stress induced by $\mathrm{H}_{2} \mathrm{O}_{2}$. $\mathrm{AD}$ patients also showed a diminished repair of $\mathrm{H}_{2} \mathrm{O}_{2}$-induced oxidized purines. ${ }^{17}$

$\mathrm{PD}$ is the second most prevalent age-related neurodegenerative disease after $\mathrm{AD}$ with physiological manifestations including tremors, bradykinesia, abnormal postural reflexes, rigidity and akinesia. ${ }^{41}$ The pathogenic mechanism of the disease is not clear and oxidative stress seems to be one of the main etiological factors. In PD patients, the dopaminergic neurons are subjected to oxidative stress resulting from reduced levels of antioxidant defenses such as glutathione and high amount of intracellular iron. Several pro-oxidant conditions have been demonstrated in midbrain tissue from PD patients, including increased levels of iron and decreased levels of GSH, which can cause the increased appearance of oxidative products of lipids, proteins, and DNA., 42, 43 The expression of high 8oxoguanine DNA glycosylase (OGG1) levels has been found in PD patients as the expression of increased repair of DNA oxidative damage. ${ }^{28}$ The increase of 8-oxo-guanine in mitochondrial DNA of $\mathrm{PD}$ patients as the occurrence of oxidative damage in nucleic acids has also been shown. ${ }^{44}$

In this study, the DNA damage as measured by comet assay was found to be significantly higher in the lymphocytes of the patients with PD compared to their healthy controls $(\mathrm{p}<0.05)$. Our findings are consistent with the very few studies done by comet assay. Petrozzi et al. performed the human lymphocyte micronucleus assay (HLMNA) and comet assay in $19 \mathrm{PD}$ patients and 16 healthy controls. ${ }^{26}$ PD patients showed a significantly increase in spontaneous $\mathrm{MN}$ frequency $(\mathrm{p}<0.001)$ and single strand break (SSB) levels $(\mathrm{p}<0.001)$ and oxidized purine base levels $(\mathrm{p}<0.05)$, supporting the hy- pothesis of oxidative stress as a relevant factor in the pathogenesis of $\mathrm{PD}$. The presence of oxidative damage has been shown in leukocytes of untreated $\mathrm{PD}$ patients, supporting the hypothesis that $\mathrm{PD}$ is a systematic disorder. Migliorei and Coppede and Prigione et al. also showed higher level of oxidative stress in the peripheral lymphocytes from PD patients compared to healthy controls. ${ }^{1,45}$ However in the lymphocytes of our patients with $\mathrm{PD}$, no significant increase in DNA strand breakage was found after treatment with only $\mathrm{H}_{2} \mathrm{O}_{2}$ and with $\mathrm{H}_{2} \mathrm{O}_{2}$ and Fpg, compared to their healthy controls (Figure 1). In our study population, the majority of patients with PD (18 PD patients) had been treated with levodopa plus dopa-dicarboxylase (DDC) inhibitors such as benserazide and carbidopa for more than 5 years. Levodopa (LP) is widely used for the symptomatic treatment of $\mathrm{PD}$, but its role in oxidative damage control is not clear. There have been controversial ideas about the toxicity of LD. Although it has been shown in some studies that LD treatment enhanced oxidative processes as measured by higher levels of lipoprotein oxidation in plasma and cerebrospinal fluid of PD patients ${ }^{46}$, some recent studies even suggested a negative correlation between oxidative stress and LD dosage ${ }^{45}$ showed that LD daily dosage is inversely correlated with ROS levels and positively associated with the activity of GSH reductase. Agil et al. also showed an inverse correlation between LD intake and plasma lipid peroxidation. ${ }^{29}$

Similar to our results, although the number of patients was limited to only nine patients compared to nine controls, Cornetta et al. observed that PD patients after $15 \mathrm{~h}$ washout of the LD therapy showed high levels of DNA single strand breaks compared to healthy controls. ${ }^{4}$ After the intake of LD therapy, a progressive and significant reduction of DNA damage up to $3 \mathrm{~h}$ from the administration of the appropriate dose is observed. It is also assumed that LD therapy exerts a long-lasting protection against oxidative stress in $\mathrm{PD}$ patients. The authors concluded that the accumulation of DNA lesions in PD patients was high, but these lesions decreased after LD intake. In addition, a recent paper by Oli et al. has demonstrated in vitro that 
dopamine and L-DOPA possess an antioxidant capacity, but are also be able to increase the levels of 8-oxodG, an oxidative stres biomarker, without manifestation of chromosomal damage. ${ }^{47} \mathrm{Zhu}$ et al. hypothesized an adaptive response of neurons towards oxidative stress since they found that only few vulnerable neurons show clear signs of apoptosis, suggesting that the level of oxidative stress does not significantly exceed neuronal oxidative defenses. ${ }^{48}$ They proposed that neurons of AD patients were exposed to low but chronic levels of oxidative stress that led them to elicit adaptive responses such as activation of stress-activated protein kinase pathways.

On the other hand, MS is a common, often disabling disease of central nervous system. Little is known about its cause or the factors that contribute to its unpredictable course. There is not enough study in the literature regarding the role of oxidative stress in patients with MS. Reactive oxygen species and nitric oxide intermediates are produced by activated macrophages and microglia and thus, they are likely candidates to be involved in tissue injury in multiple sclerosis. ${ }^{49}$ Calabrese et al. support the role for nitrosative stress in the pathogenesis of MS and indicate that therapeutic strategies focused on decreasing production of NO by inducible NO synthase and/or scavenging peroxynitrite may be useful in alleviating the neurological impairments that occur during MS relapse. It is likely that peroxynitrite scavengers, specific inhibitors of iNOS, and/or modulators of GSH levels may be of use in therapy for MS, especially during relapse. ${ }^{50}$ Oxidized lipids and oxidized DNA have been detected biochemically in brain tissue from patients with MS. ${ }^{51-54}$ Haider et al. suggested profound oxidative injury of oligodendrocytes and neurons to be associated with active demyelination and axonal or neuronal injury in MS. ${ }^{55}$ Satoh et al. reported that MS lymphocytes had a complex pattern of gene regulation that represented a counterbalance between promoting and preventing apoptosis and DNA damage of lymphocytes. ${ }^{56}$ Our study is the first study that has examined the DNA damage in the lymphocytes of patients with MS by comet assay. In our study, although the basal DNA damage was higher in $22 \mathrm{MS}$ patients compared to their 16 healthy controls, the difference was not statistically significant. However a significant increase in the tail moment which is a reliable indicator of DNA damage after treatment of lymphocytes with $\mathrm{H}_{2} \mathrm{O}_{2}$ and post-treatment with Fpg have been observed in the patients with MS compared to their healthy controls suggesting the susceptibility to oxidative DNA damage in these patients.

\section{CONCLUSION}

In conclusion, the data presented in this paper shows high level of DNA damage in the lymphocytes of patients with PD and MS, and indicates the possibility of oxidative stres in these neurodegenerative diseases. It is likely that antioxidants may be of use in therapy especially for MS. However, in order to make a definite conclusion and to investigate the possible mechanisms of these diseases, further studies are needed.

\section{REFERENCES}

1. Migliore L, Coppedè F. Genetic and environmental factors in cancer and neurodegenerative diseases. Mutat Res 2002;512(2-3):13553.

2. Mariani E, Polidori MC, Cherubini A, Mecocci $P$. Oxidative stress in brain aging, neurodegenerative and vascular diseases: an overview. J Chromatogr B Analyt Technol Biomed Life Sci 2005;827(1):65-75.

3. Brambilla D, Mancuso C, Scuderi MR, Bosco P, Cantarella G, Lempereur L, et al.
The role of antioxidant supplement in immune system, neoplastic, and neurodegenerative disorders: a point of view for an assessment of the risk/benefit profile. Nutr J 2008;7:29. doi: 10.1186/1475-2891-729.

4. Cornetta T, Palma S, Aprile I, Padua L, Tonali $\mathrm{P}$, Testa A, et al. Levodopa therapy reduces DNA damage in peripheral blood cells of patients with Parkinson's disease. Cell Biol Toxicol 2009;25(4):321-30.
5. Marcus DL, Thomas C, Rodriguez C, Simberkoff K, Tsai JS, Strafaci JA, et al. Increased peroxidation and reduced antioxidant enzyme activity in Alzheimer's disease. Exp Neurol 1998;150(1):40-4.

6. Perry G, Nunomura A, Hirai K, Zhu X, Pérez $M$, Avila J, et al. Is oxidative damage the fundamental pathogenic mechanism of Alzheimer's and other neurodegenerative diseases? Free Radic Biol Med 2002;33(11): 1475-9. 
7. Gibson GE, Huang HM. Oxidative stress in Alzheimer's disease. Neurobiol Aging 2005;26 (5):575-8

8. Praticò D. Peripheral biomarkers of oxidative damage in Alzheimer's disease: the road ahead. Neurobiol Aging 2005;26(5):581-3.

9. Ercan A, Kulaksız G, Dalmızrak Ö, Müftüoğlu $M, O ̈$ Öüş H, Çavdar L, et al. Mitochondrial respiratory chain enzyme activities, mtDNA variants and gene expression levels in idiopathic Parkinson's disease. Turk J Biochem 2009; 34(2):97-104.

10. Kurban S, Akpınar Z, Mehmetoğlu i. [Investigation of serum paraoxonase and arylesterase activities and oxidative stres in patients with multiple sclerosis]. Genel Tip Derg 2010;20 (1):13-7.

11. Mecocci $P$, Polidori MC, Ingegni $T$, Cherubini A, Chionne F, Cecchetti R, et al. Oxidative damage to DNA in lymphocytes from AD patients. Neurology 1998;51(4):1014-7.

12. Gabbita SP, Lovell MA, Markesbery WR. Increased nuclear DNA oxidation in the brain in Alzheimer's disease. J Neurochem 1998;71 (5):2034-40

13. Prasad MR, Lovell MA, Yatin M, Dhillon $\mathrm{H}$, Markesbery WR. Regional membrane phospholipid alterations in Alzheimer's disease. Neurochem Res 1998;23(1):81-8.

14. Lovell MA, Gabbita SP, Markesbery WR. Increased DNA oxidation and decreased levels of repair products in Alzheimer's disease ventricular CSF. J Neurochem 1999;72(2): 771-6.

15. Nunomura A, Perry G, Pappolla MA, Wade R, Hirai $\mathrm{K}$, Chiba $\mathrm{S}$, et al. RNA oxidation is a prominent feature of vulnerable neurons in Alzheimer's disease. J Neurosci 1999;19(6): 1959-64.

16. Migliore L, Fontana I, Colognato R, Coppede $F$, Siciliano G, Murri L. Searching for the role and the most suitable biomarkers of oxidative stress in Alzheimer's disease and in other neurodegenerative diseases. Neurobiol Aging 2005;26(5):587-95.

17. Mórocz M, Kálmán J, Juhász A, Sinkó I, McGlynn AP, Downes CS, et al. Elevated levels of oxidative DNA damage in lymphocytes from patients with Alzheimer's disease. Neurobiol Aging 2002;23(1):47-53.

18. Kadioglu E, Sardas S, Aslan S, Isik E, Esat Karakaya A. Detection of oxidative DNA damage in lymphocytes of patients with Alzheimer's disease. Biomarkers 2004;9(2):203-9.

19. Migliore L, Fontana I, Trippi F, Colognato R, Coppedè $F$, Tognoni $G$, et al. Oxidative DNA damage in peripheral leukocytes of mild cognitive impairment and $A D$ patients. Neurobiol Aging 2005;26(5):567-73.

20. Lewis CD, Laemmli UK. Higher order metaphase chromosome structure: evidence for metalloprotein interactions. Cell 1982;29(1): 171-81.

21. Collins AR, Dusinská M, Gedik CM, Stětina R. Oxidative damage to DNA: do we have a reliable biomarker? Environ Health Perspect 1996;104(Suppl 3):465-9.

22. Jaruga $P$, Dizdaroglu M. Repair of products of oxidative DNA base damage in human cells. Nucleic Acids Res 1996;24(8):1389-94.

23. Cecchi $C$, Fiorillo $C$, Sorbi $S$, Latorraca $S$, Nacmias B, Bagnoli S, et al. Oxidative stress and reduced antioxidant defenses in peripheral cells from familial Alzheimer's patients. Free Radic Biol Med 2002;33(10):1372-9.

24. Mecocci $P$, Polidori MC, Cherubini $A$, Ingegni $\mathrm{T}$, Mattioli $\mathrm{P}$, Catani M, et al. Lymphocyte oxidative DNA damage and plasma antioxidants in Alzheimer disease. Arch Neurol 2002;59 (5):794-8.

25. Gasser T. Genetics of Parkinson's disease. Curr Opin Neurol 2005;18(4):363-9.

26. Petrozzi L, Lucetti $C$, Gambaccini $G$, Bernardini S, Del Dotto P, Migliore L, et al. Cytogenetic analysis oxidative damage in lymphocytes of Parkinson's disease patients. Neurol Sci 2001;22(1):83-4.

27. Migliore L, Petrozzi L, Lucetti C, Gambaccini G, Bernardini S, Scarpato R, et al. Oxidative damage and cytogenetic analysis in leukocytes of Parkinson's disease patients. Neurology 2002;58(12):1809-15.

28. Fukae J, Takanashi M, Kubo S, Nishioka K, Nakabeppu Y, Mori $\mathrm{H}$, et al. Expression of 8oxoguanine DNA glycosylase (OGG1) in Parkinson's disease and related neurodegenerative disorders. Acta Neuropathol 2005; 109(3):256-62.

29. Agil A, Durán R, Barrero F, Morales B, Araúzo $M$, Alba $F$, et al. Plasma lipid peroxidation in sporadic Parkinson's disease. Role of the Ldopa. J Neurol Sci 2006;240(1-2):31-6.

30. Martin R, McFarland HF. Immunological aspects of experimental allergic encephalomyelitis and multiple sclerosis. Crit Rev Clin Lab Sci 1995;32(2):121-82.

31. Keegan BM, Noseworthy JH. Multiple sclerosis. Annu Rev Med 2002;53:285-302.

32. Tice RR, Agurell E, Anderson D, Burlinson B, Hartmann A, Kobayashi H, et al. Single cell gel/comet assay: guidelines for in vitro and in vivo genetic toxicology testing. Environ $\mathrm{Mol}$ Mutagen 2000;35(3):206-21.

33. Bøyum A. Isolation of lymphocytes, granulocytes and macrophages. Scand J Immunol 1976;(Suppl 5):9-15.

34. Singh NP, McCoy MT, Tice RR, Schneider EL. A simple technique for quantitation of low levels of DNA damage in individual cells. Exp Cell Res 1988;175(1):184-91.
35. Collins AR, Dobson VL, Dusinská M, Kennedy G, Stětina R. The comet assay: what can it really tell us? Mutat Res 1997;375(2): 183-93.

36. Hoehn MM, Yahr MD. Parkinsonism: onset, progression and mortality. Neurology 1967;17 (5):427-42.

37. Knopman DS, DeKosky ST, Cummings JL, Chui $\mathrm{H}$, Corey-Bloom J, Relkin N, et al. Practice parameter: diagnosis of dementia (an evidencebased review). Report of the Quality Standards Subcommittee of the American Academy of Neurology. Neurology 2001;56(9):1143-53.

38. DeKosky ST, Ikonomovic MD, Styren SD, Beckett L, Wisniewski S, Bennett DA, et al. Upregulation of choline acetyltransferase activity in hippocampus and frontal cortex of elderly subjects with mild cognitive impairment. Ann Neurol 2002;51(2):145-55.

39. Rusinek H, De Santi S, Frid D, Tsui WH, Tarshish CY, Convit A, et al. Regional brain atrophy rate predicts future cognitive decline: 6 -year longitudinal MR imaging study of normal aging. Radiology 2003;229(3):691-6.

40. Nunomura A, Perry G, Aliev G, Hirai K, Takeda A, Balraj EK, et al. Oxidative damage is the earliest event in Alzheimer disease. $\mathrm{J}$ Neuropathol Exp Neurol 2001;60(8):759-67.

41. Olanow CW, Agid Y, Mizuno Y, Albanese A, Bonuccelli $U$, Damier $P$, et al. Levodopa in the treatment of Parkinson's disease: current controversies. Mov Disord 2004;19(9):997-1005.

42. Sian J, Dexter DT, Lees AJ, Daniel S, Jenner $P$, Marsden CD. Glutathione-related enzymes in brain in Parkinson's disease. Ann Neurol 1994;36(3):356-61.

43. Miller RL, James-Kracke M, Sun GY, Sun AY. Oxidative and inflammatory pathways in Parkinson's disease. Neurochem Res 2009;34(1): 55-65.

44. Nakabeppu Y, Tsuchimoto D, Yamaguchi $\mathrm{H}$, Sakumi K. Oxidative damage in nucleic acids and Parkinson's disease. J Neurosci Res 2007;85(5):919-34.

45. Prigione A, Begni B, Galbussera A, Beretta S, Brighina L, Garofalo R, et al. Oxidative stress in peripheral blood mononuclear cells from patients with Parkinson's disease: negative correlation with levodopa dosage. Neurobiol Dis 2006;23(1):36-43.

46. Buhmann C, Arlt S, Kontush A, Möller-Bertram T, Sperber S, Oechsner M, et al. Plasma and CSF markers of oxidative stress are increased in Parkinson's disease and influenced by antiparkinsonian medication. Neurobiol Dis 2004;15(1):160-70.

47. Oli RG, Fazeli G, Kuhn W, Walitza S, Gerlach $M$, Stopper $H$. No increased chromosomal damage in L-DOPA-treated patients with Parkinson's disease: a pilot study. J Neural Transm 2010;117(6):737-46. 
48. Zhu X, Raina AK, Lee HG, Chao M, Nunomura $A$, Tabaton $M$, et al. Oxidative stress and neuronal adaptation in Alzheimer disease: the role of SAPK pathways. Antioxid Redox Signal 2003;5(5):571-6.

49. van Horssen J, Schreibelt G, Drexhage J, Hazes T, Dijkstra CD, van der Valk $P$, et al. Severe oxidative damage in multiple sclerosis lesions coincides with enhanced antioxidant enzyme expression. Free Radic Biol Med 2008;45(12):1729-37.

50. Calabrese V, Scapagnini G, Ravagna A, Bella $R$, Foresti $R$, Bates TE, et al. Nitric oxide synthase is present in the cerebrospinal fluid of patients with active multiple sclerosis and is associated with increases in cerebrospinal fluid protein nitrotyrosine and S-nitrosothiols and with changes in glutathione levels. J Neurosci Res 2002;70(4):580-7.

51. Vladimirova O, O'Connor J, Cahill A, Alder H, Butunoi C, Kalman B. Oxidative damage to DNA in plaques of MS brains. Mult Scler 1998;4(5):413-8.

52. Smith KJ, Kapoor R, Felts PA. Demyelination: the role of reactive oxygen and nitrogen species. Brain Pathol 1999;9(1):6992.

53. Bizzozero OA, DeJesus G, Callahan K, Pastuszyn $A$. Elevated protein carbonylation in the brain white matter and gray matter of patients with multiple sclerosis. J Neurosci Res
2005;81(5):687-95.

54. Qin J, Goswami R, Balabanov R, Dawson G. Oxidized phosphatidylcholine is a marker for neuroinflammation in multiple sclerosis brain. J Neurosci Res 2007;85(5):977-84.

55. Haider L, Fischer MT, Frischer JM, Bauer J, Höftberger R, Botond $\mathrm{G}$, et al. Oxidative damage in multiple sclerosis lesions. Brain 2011;134(Pt 7):1914-24.

56. Satoh J, Nakanishi M, Koike F, Miyake S, Yamamoto $T$, Kawai $M$, et al. Microarray analysis identifies an aberrant expression of apoptosis and DNA damage-regulatory genes in multiple sclerosis. Neurobiol Dis 2005;18(3):53750. 